
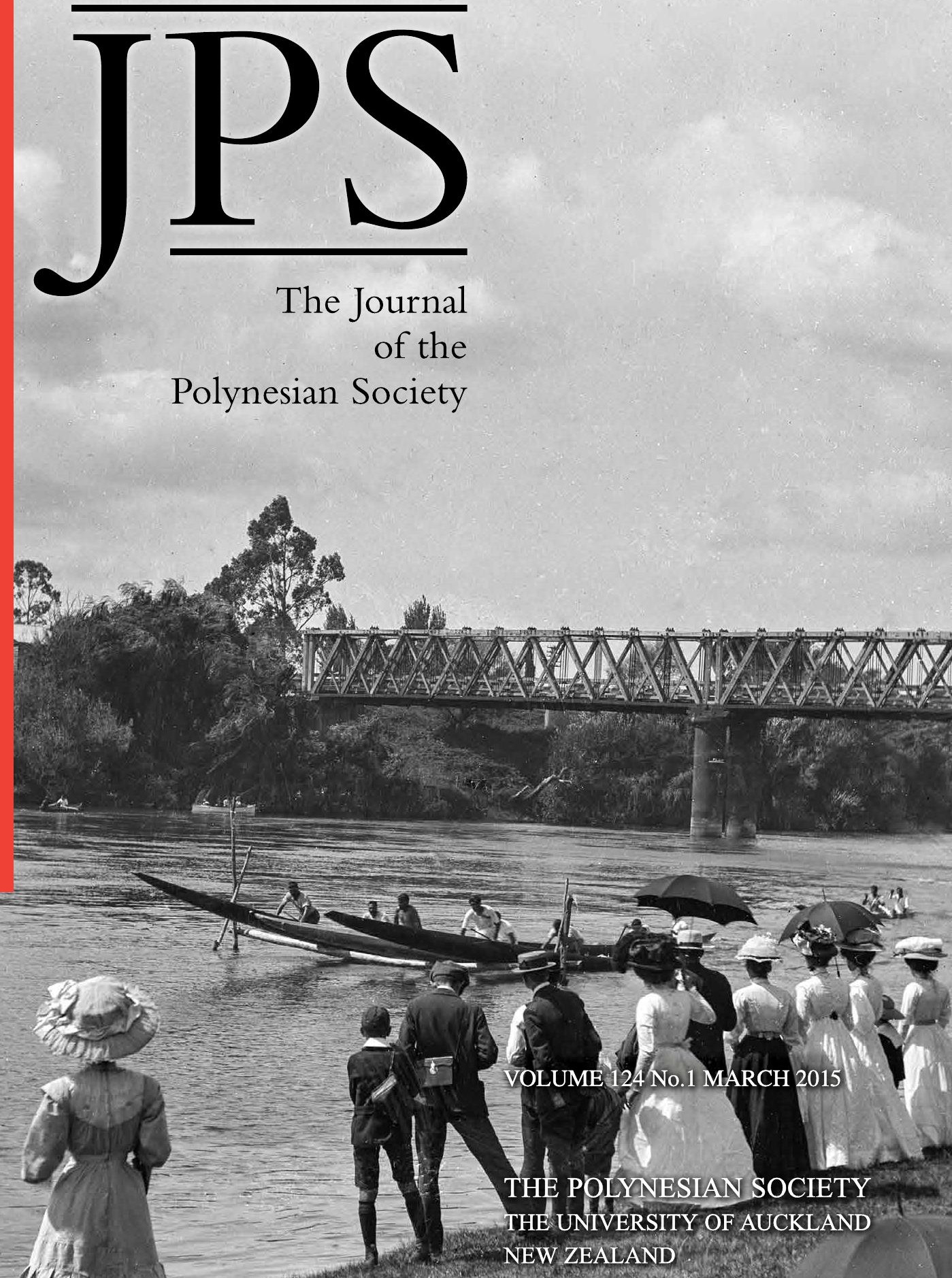


\title{
THE NGĀRUAWĀHIA TŪRANGAWAEWAE REGATTA: TODAY'S REFLECTIONS ON THE PAST
}

\author{
TANGIWAI REWI \\ University of Otago
}

\begin{abstract}
Ko Taupiri, ko Onepoto, ko Te Puke o Tahinga ngā maunga, ko Waikato te awa, ko Tainui te waka, ko Waikato te iwi, ko Pōtatau te tangata. Ko Ngāti Amaru, ko Ngāti Tipa, ko Ngāti Tahinga ngā hapū, ko Te Awamarahi, ko Te Kotahitanga, ko Oraeroa, ko Weraroa ngā marae. Nō Te Puaha o Waikato ahau.

My whakapapa 'genealogy' ties to the Taupiri, Onepoto and Te Puke o Tahinga mountains, the Waikato River, the Tainui Canoe, the Waikato Tribe and the esteemed Chief Pōtatau. I belong to the subtribes of Ngāti Amaru, Ngāti Tipa and Ngāti Tahinga and my marae 'Māori communal complexes' are Te Awamarahi, Te Kotahitanga, Oraeroa and Weraroa.
\end{abstract}

The township of Ngāruawāhia lies at the confluence of the Waikato and Waipa Rivers and is home to the Ngāruawāhia Tūrangawaewae Regatta. First held in 1896 , this is one of the country's oldest regattas, second only to the Auckland Regatta of the $1870 \mathrm{~s}$. Although initially a social event centred on water sports, it has come to be closely associated with the Māori King Movement or Kingitanga. This political movement, dating from 1858, was initially aimed at giving Māori tribes leverage in their dealings with the British Monarchy: today it is more broadly associated with Maori aspirations for social, political, cultural and economic self-determination, including the Regatta described herein. Here I trace the history of the Ngāruawāhia Tūrangawaewae Regatta, from its inception to the present day, focussing on how it has promoted kotahitanga 'embracing togetherness' within Ngāruawāhia and the Waikato Region and more generally across Aotearoa/New Zealand. A change in the Regatta's venue, from The Point, a community park at the confluence of the Waikato and Waipa Rivers, to Türangawaewae Marae, is identified as pivotal with respect to the event's social and cultural meanings.

The exact beginning of the Ngāruawāhia Tūrangawaewae Regatta was on St Patrick's Day, 17 March 1896, in honour of the patron saint of Ireland. This date was deliberately chosen at the suggestion of one of the first engineers of Irish descent in Ngāruawāhia, who was credited with building the first railway bridge in 1876 , or so "Ben" told me. The day would come to be viewed as a social event for all workers and would continue to be held on 17 March or the weekend closest to it. Some knowledgeable people from Türangawaewae Marae said that the Mayor initially requested or invited the Māori community to join in the Regatta, and it has come to capture the 
unique links between Ngāruawāhia Māori and Pākehā, also symbolised by the convergence of the Waipa and the Waikato Rivers and even the name now given to the celebration itself. Resident Glenda Raumati (pers. comm, 2013) explained the name's history as follows:
Until 1973 it was called the Ngāruawāhia Regatta and then was renamed the Türangawaewae Regatta. In honour of its 100th centennial in 1996, it was called the Ngāruawāhia Tūrangawaewae Māori Aquatic Regatta for that year only, incorporating the two names of importance within that community. The name reverted to its original title, the Ngāruawāhia Regatta, from 1996 until it was changed back to the Türangawaewae Regatta in 2012.

I shall simply refer to it as the Regatta. The reason it was first celebrated all those years ago remains clear and unchanged: "to encourage various forms of aquatic sports and Māori activities, with particular emphasis on the preservation of their ancient customs and traditions" (Ngāruawāhia/ Tūrangawaewae Centennial Committee 1996: 5).

The Waikato River, my awa 'river', is an important presence in my life, and this attachment prompted me to write this article. I was born among my people at the mouth of the Waikato River where it runs out to the Tasman Sea. My family later moved upriver, nearer to the source of the Waikato and about $32 \mathrm{~km}$ southwest of Taupo, where the Waikato River flowed at the back of the farm. Yet we returned regularly to our ancestral marae for familial and other events, particularly those of my mother's side of the family which was heavily involved in Kingitanga. This connection brought us to Ngāruawāhia on many occasions. I cannot claim to have ever lived in Ngāruawāhia, yet the town remains a place of special memories and connections for me; my father's late tuakana 'elder brother' still had his family home on George Street, now occupied by his son and his family. There we visited and stayed for many Kīngitanga Coronation ${ }^{2}$ and Regatta days. I joined Ngāruawāhia sports clubs while teacher-training (an internship) in the area and later briefly taught nearby and became involved in the daily events of the marae. ${ }^{3}$ Memories, after a decade's absence from the Waikato, drew me back to the riverbanks once again.

I begin this article with my three day experience, recorded in a journal written in 2013, of the 118th Regatta: on Friday the waka kopapa ${ }^{4}$ or dug-out canoe races for school children, on Saturday the celebration and that night spent with the Te Atiawa delegates in the Pare Waikato wharenui 'sleeping house' at Türangawaewae Marae and finally, on Sunday, the farewells and big clean-up after the visitors had left. This first section is written as a narrative, drawing on my journal, aimed at capturing the immediacy of what I was experiencing and seeing. 


\section{A 2013 REGATTA EXPERIENCE}

It had been such a long time since I had attended the Regatta from a Friday start, so I fully intended to be there from the "get go" at 9.00 am and to remain there through to the end of clean-up on the Sunday. I was curious to know whether my cherished Regatta memories from childhood through to adolescence, and as a young teacher, would be confirmed or bettered by a modern 2013 Regatta experience.

\section{School Childrens'Waka Kopapa Race Day}

The riverbank was already bustling, with school visitors jostling for the best viewing positions and quickly claiming the pre-erected marquees and tarpaulin shelters for the day. The first waka kopapa races were scheduled to start at 9.30 am (Fig. 1). The banks were filled with a mix of uniformed children, parents, grandparents, aunts, uncles and teachers, all preparing for the first races and ensuring their teams had registered. The intercom was blaring out the names of those schools yet to check in.

Soaking up this atmosphere, I was amazed at how the Friday event had grown, maybe quadrupled, from the last time I had attended the schools' race day, some 15 years before. At that time, only teenaged secondary school students from the region competed, but on this day I witnessed children of all ages taking part, with most hailing from local schools or schools from the immediately surrounding districts. One teacher pointed out:

That wee girl has just turned five and this is her third day at school. We didn't have enough junior boys so I asked her if she wanted to paddle. I don't think she has ever been in a waka kopapa before but look at her, anyone would think she has been doing this for ages!

The pint-sized paddler certainly handled her hoe 'paddle' like an expert, without a care in the world and in unison with the rest of her team as their waka raced down river to the finish line. I would have been none the wiser about her novice status had this not been pointed out to me. Never once in the day did I feel anxious for the paddlers' safety or wellbeing as they deftly maneuvered their craft out into the swift flowing current, then back to shore. The support craft on the river also helped keep my anxiety at bay. With six members in a team, easily the most critical role is that of the steerer. The Waikato River has dangerous currents and this stretch is no different, causing even the most experienced adults grief when paddling the much larger waka taua 'war canoes' during the Saturday festivities.

The assumption that the local schools would take all the "silverware" (trophies) was quickly put to rest, as the winners of the various heats appeared to have come from several districts. I think it meritorious that Friday's purpose 


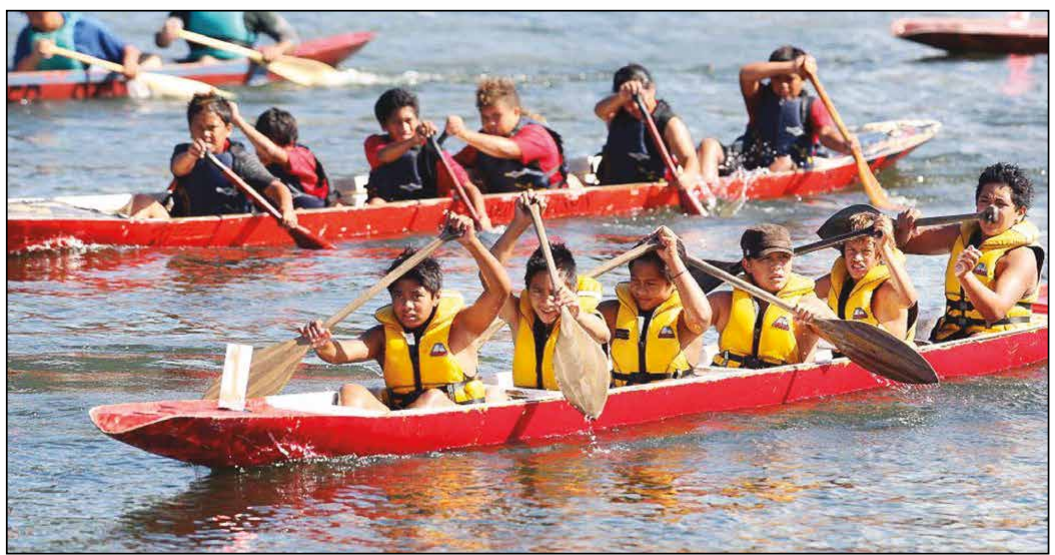

Figure 1. School teams competing in a waka kopapa race. Photo from Tūrangawaewae Regatta Facebook (TRFB) page, March 2013.

is to race all the heats, with the finals being saved for the Saturday, in front of a much bigger audience. Either way, proud whänau 'families' were there in support on both days.

Other than the aquatic activity on the river, a carnival, festive and fair-like atmosphere already prevailed. Food stalls selling a variety of hot and cold selections were doing a roaring trade. The usual sugary treats had caught the children's attention, and parents and grandparents could be seen being lead off to particular stalls. The attraction rides were not due to open until later that afternoon so that part of the grounds remained quiet.

As the day ended, I reflected upon what I had observed and one comment held fast in my mind. It was from another former, non-Māori teaching colleague at one of the local area schools, whom I have known for many years:

I'm so busy with my IT responsibilities at school and for our cluster that I can't even afford to be here. But this is what it's all about, bringing our students to events like these - they need to celebrate who they are, they need to live these types of experiences, enjoy them and know they are good at them. You cannot teach this back in the classroom.

As I reflected on my friend's remarks, I was reminded that teaching and learning comes in many different forms and neither should be restricted to the confines of a classroom. Even though some schools may have access to the sea, the river or estuaries for training purposes, I imagine posing a 
pseudo waka kopapa race outside of the real thing would be very hard. I am a staunch supporter of giving students a living and breathing experience and, as much as I could go to great lengths to describe it, I do not believe anything can replace being at the Regatta waka kopapa races and experiencing them first-hand. As I glanced around, I wondered how many of the paddlers, their teachers and whänau from all schools could whakapapa 'link genealogically' back to someone that may have participated in these same pursuits over the 118 years the Regatta has been celebrated. I would think this might be the reality for only a selected few. Looking towards the future, however, I would like to think that the numbers will be significantly increased.

\section{Regatta Day}

On Saturday, the unbothered attitude to parking from the previous day had well and truly disappeared. I followed the signs to Gate 4 and at 8.45 am parked the car for a gold coin donation. The entrance fee to the marae grounds is $\$ 5.00$, or more if you wanted to make a donation. I noticed guided tours of Türangawaewae Marae were available at a small cost, something that was new to me. Immediately, low-toned, rhythmic male chanting caught my attention and I watched as the waka taua crews nearby went through their final paddling and timing drills before the first of two ceremonial parades they would make on the river, one at $11 \mathrm{am}$ and the other at $3 \mathrm{pm}$. I passed four crews in succession, each immersed in their own final preparations, as I headed to the riverbank (Fig. 2).

The air was a pungent mix of delicious aromas that are synonymous with Regatta and a vicarious welcome home banner to me. I visited the market place te whare roa 'long house', which offered a variety of food and merchandise, stands with information on health, wellbeing, and education, as

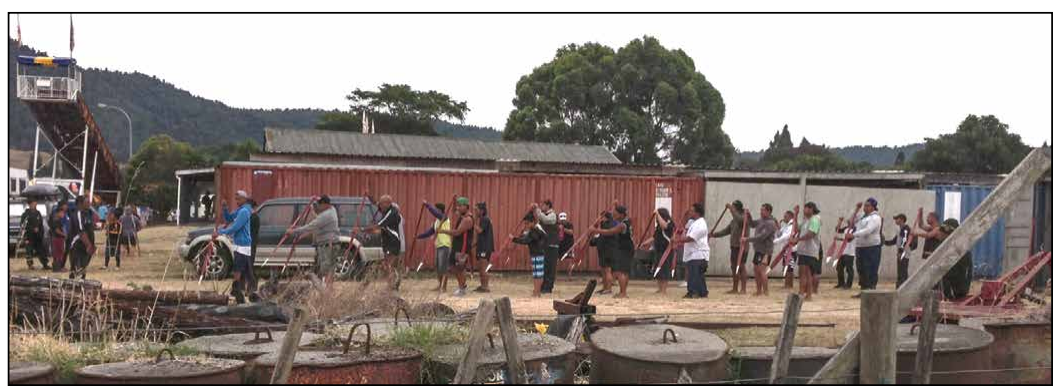

Figure 2. A waka taua crew practising their routine before paddling in the first ceremonial parade (March 2013). 
well as raffles for kete 'woven flax baskets' of all shapes and sizes. There was a variety of goods on sale, from arts and crafts, to clothing and accessories. A must have is a Regatta tee shirt which I duly purchased. There were also demonstrations of tā moko 'tattooing', raranga 'weaving' and whakairo 'carving'. A popular stand saw people dressed in olden day or period clothes being photographed, complete with mock moko kauae 'chin tattoos'. The effects were surreal and I wished I had my mokopuna 'grandchild' with me so I too could be photographed with him. Living in the south, away from my own rohe 'home region', I immersed myself in the important activity of whakawhanaungatanga 'relationship maintenance' when, at $11 \mathrm{am}$, I realised the first waka taua had reached the barge. You could feel tension in the air as the anticipation levels of the crowd and rangatira 'captain' of each waka were elevated. Each wondered whether the rangatira had timed his commands to effectively turn his waka past the barge, sweep back around, then draw up alongside the latter to salute King Tuheitia and his guests before paddling upstream again. Only once have I witnessed a waka partially sinking when it did not make the turn in time but that is another story.

This year's visiting waka, Te Aniwaniwa, was from a delegation of the Te Atiawa $i w i$ 'tribe' from Waiwhetu in Lower Hutt. Having first participated in the Regatta in 2012, the Waikato River currents did not disrupt the paddlers' flow and they completed the honour of being the first crew to salute King Tuheitia and his guests on the dais by the river barge (Fig. 3). This year's dignitaries reflected the long-standing emphasis on local, diplomatic, international and indigenous representation. The party included the local

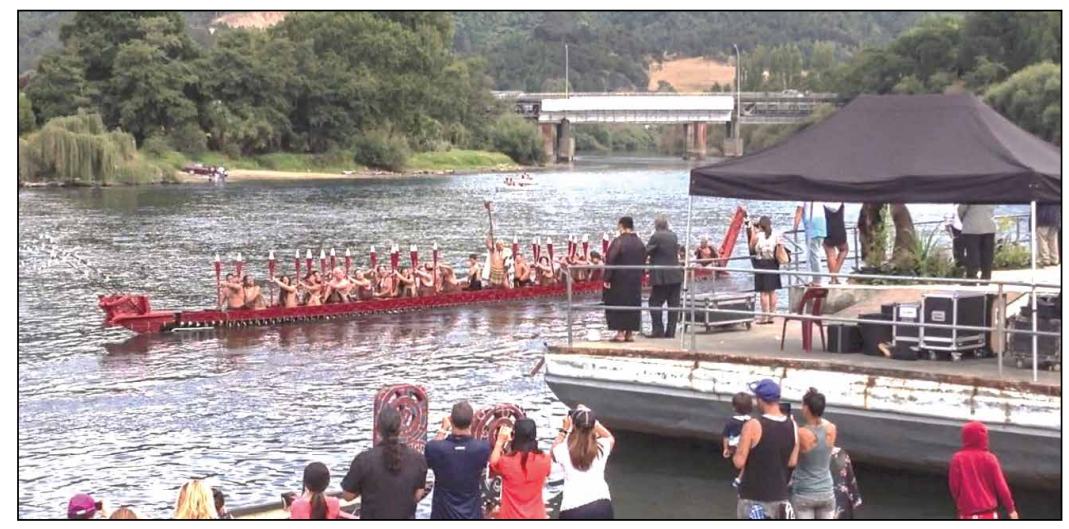

Figure 3. Another waka taua, Rangatahi, in salute to King Tuheitia and guests who are seated to the right and out of view (March 2013). 
mayor, the official Representative of the U.S. Ambassador to New Zealand and Samoa, and a group of Hawaiian celestial navigators.

The six other waka followed in quick succession. The first, Tangi Te Kiwi, was the smallest in the fleet and required the paddlers to apply more stength to ensure the waka made the turn in time. Next came the two waka commissioned by Te Wānanga o Aotearoa. Tätahiora, or the King's waka as it is more commonly known, is predominantly crewed by paddlers from Waahi Pā in Huntly. This waka is the newest in the fleet and was commissioned to commemorate the 150-year celebrations of the Kingitanga from 1858 to 2008. The Waikura came after that, crewed by Ngāti Mahanga of Waikato. Three other waka, Rangatahi, Taheretikitiki (Fig. 4) and Tumanako, the "old guard" of Regatta Day, closed out the parade. As with the opening pass, Te Aniwaniwa was also afforded the closing salute and was greeted by a rousing impromptu haka from the six other crews as they made their way back to shore (Fig. 5). As a gesture of reciprocal respect, the Te Aniwaniwa crew also responded in kind with a haka once they alighted.

The aquatics programme scheduled for Regatta Day was held in the stretch of water before the main arena. In addition to the two waka taua ceremonial parades, the schools' waka kopapa finals were scheduled intermittently, along with the adult $\mathrm{OC} 1$ waka (outrigger canoes for one person with single ama or outrigger floats) 10-km dash downstream to Taupiri and back (Fig. 6).

As with the previous day, all manner of food items were available for purchase, however, the firm favourites remained the hangi 'earth-oven cuisine' and mussel fritters, both of which quickly sold out. Seafood cooked in any style was soon sold out as well. For the numerous children present, carnival foods were popular choices, as were ice creams, cold drinks and fruit on this sunny day.

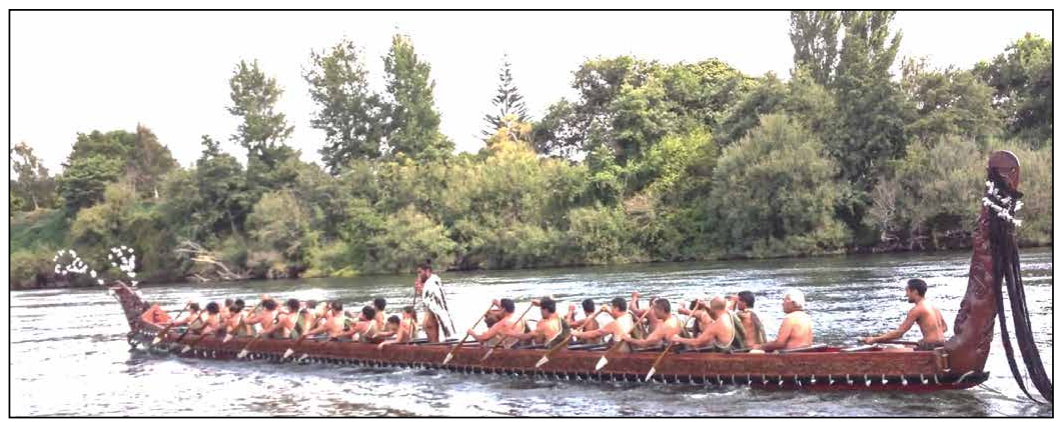

Figure 4. Taheretikitiki heads upstream and back to the shore after the closing ceremonial parade at Regatta (March 2013). 


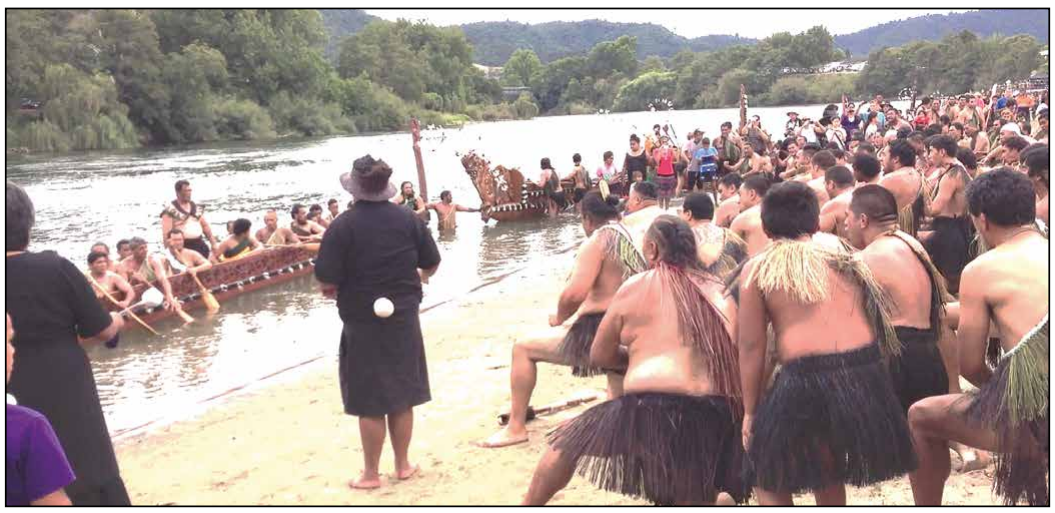

Figure 5. The six waka taua crew perform an impromptu haka in acknowledgement of the Te Aniwaniwa crew (March 2013).

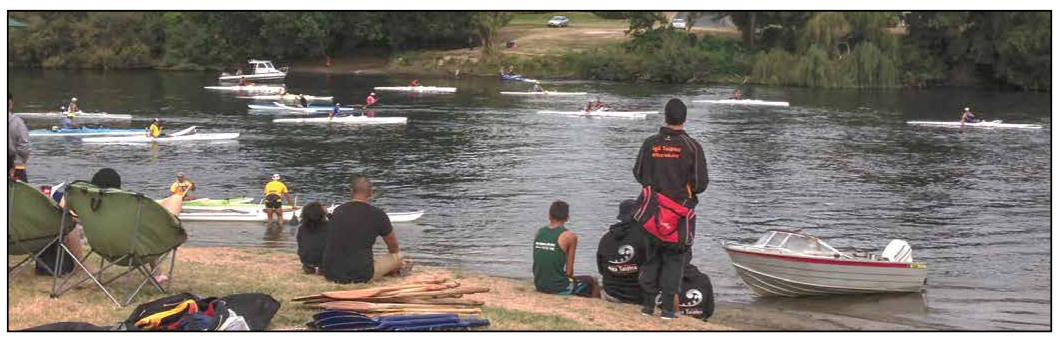

Figure 6. The adult single waka race (OCI) competitors line up ready to get underway to Taupiri and back (March 2013).

Sideshows and carnival rides also have been long-standing and popular features of the Regatta (Figs 7 and 8); I recall seeing them at each Regatta I have attended. Judging by the length of the waiting lines for tickets this year, it seemed the attraction of carnival rides and sideshows has not diminished - they were as busy as ever. I watched interactions between Māori and non-Māori, Māori and other indigenous peoples of the world, my Waikato people (mostly working the stalls) and other $i w i$, and New Zealanders and internationals visitors. It was not hard to distinguish local organisations whose national bodies had come to support their information stands or presence at the Regatta either. Even when I included Friday in the mix, there was a recurrent, underlying theme evident; students, schools, parents, whanau and spectators were all united for the one purpose of competing in the different events, partaking in the activities available or simply spectating at the 2013 Regatta. 


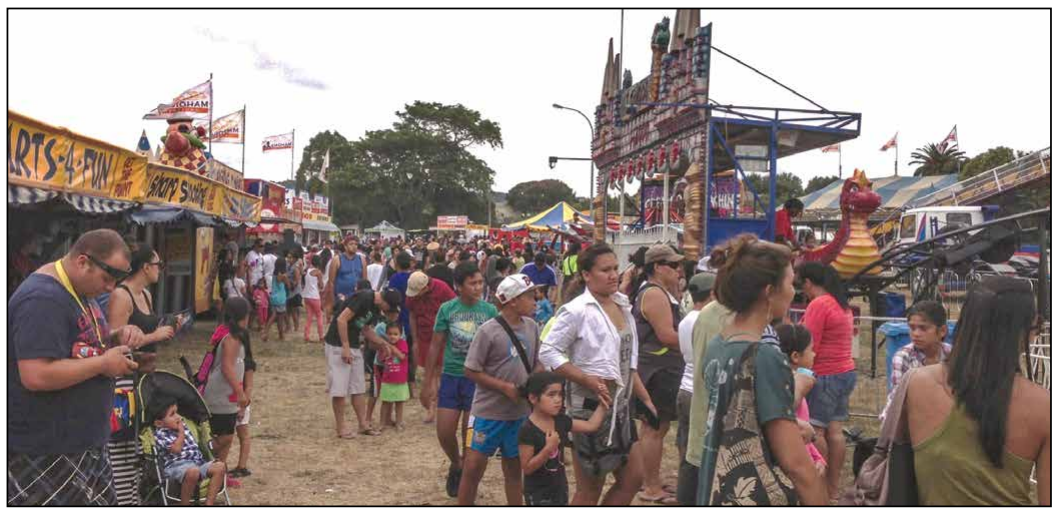

Figure 7. Queuing at a sideshow ride (March 2013).

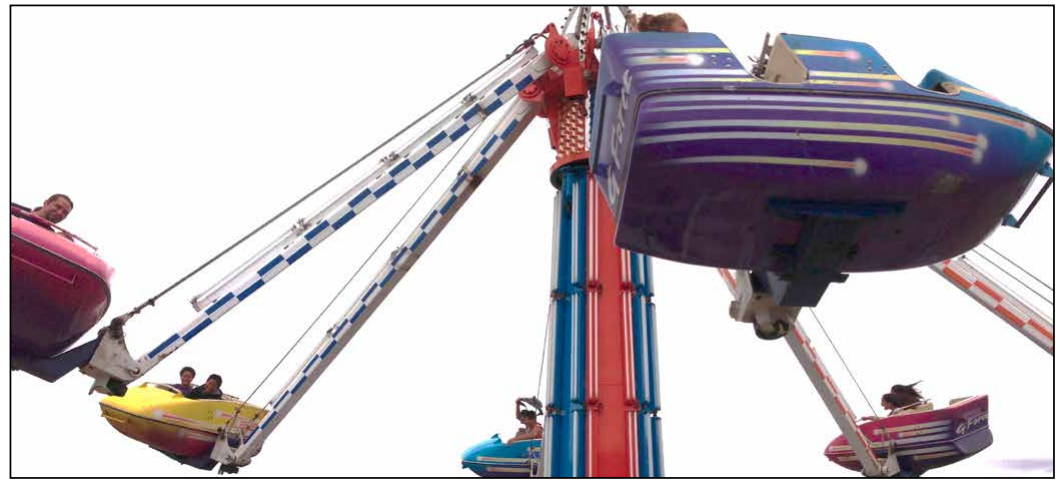

Figure 8. The ever-popular Hurricane ride for older children (March 2013).

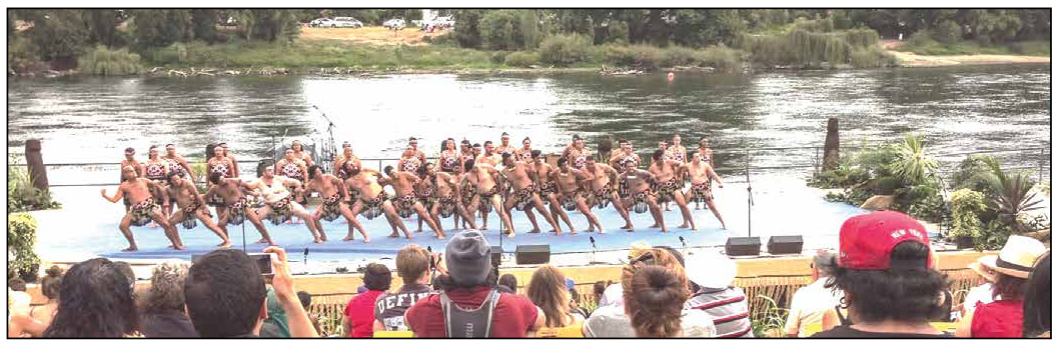

Figure 9. One of the three kapa haka troupes entertaining the crowd (March 2013). 


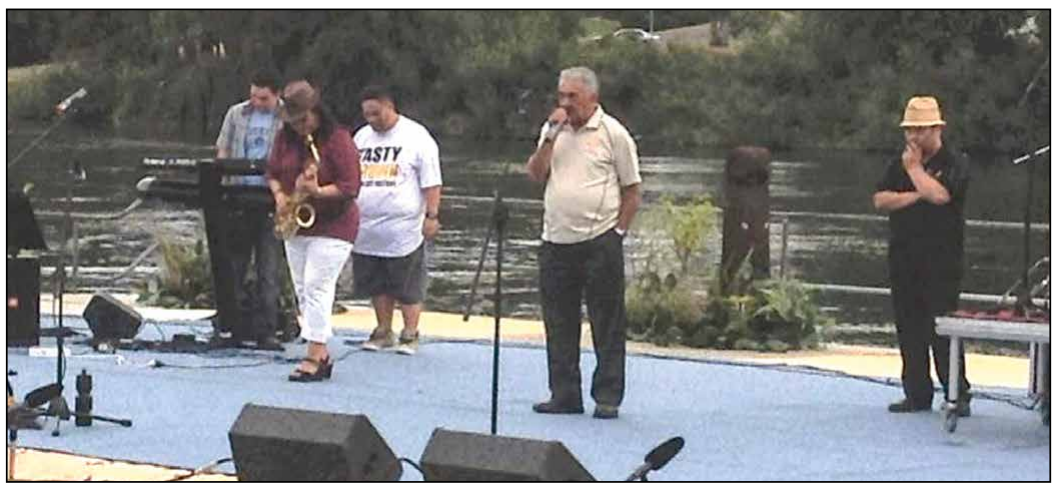

Figure 10. The last of the three bands that entertained the crowd, with the kaumātua 'male elder'offering the day's closing prayer. Photo from TRFB page, March 2013.

The main stage was a barge (Fig. 9), used in much in the same way as when the Regatta was held at The Point. It was anchored at the northern end of the riverbank, the main arena, next to the reserved seating for King Tuheitia and the invited dignitaries. This was also the Master of Ceremonies station. The entertainment this year featured the three Waikato-Tainui kapa haka 'performing arts' groups which represented the region at the National Te Matatini o Te Rā kapa haka 'Māori performing arts' competitions held in February at Rotorua. Three bands rounded off the day, with the closing karakia 'prayer' held at approximately 6 pm (Fig. 10), some nine hours after the opening karakia was offered at 9 am.

\section{The Wharenui, Pare Waikato}

An important aspect of the Regatta in previous times for many Māori visitors was the opportunity to gather and sleep in the community's wharenui or meeting house. It has been many years since I have had occasion to sleep at Tūrangawaewae Marae. Whanaunga 'relatives' from my mother's marae, Te Awamarahi, had been rostered to cater and care for the Te Atiawa delegation upon their arrival on the Friday morning. Given my close friendship with some of the Te Atiawa visitors, I chose to stay overnight on Saturday, to whakawhanaunga 'renew relationships' with them and help with the evening meal, and the breakfast preparations and to clean up the next morning. This also allowed me the opportunity to reconnect with my relatives from $\mathrm{Te}$ Awamarahi. The modern kitchen facilities in the wharekai 'kitchen and dining hall' were a pleasure to have on hand but unnecessary, as we did not have to prepare any meals from scratch but were merely reheating meals that were 
previously prepared. All that was required was a quick trip in the van about $40 \mathrm{~m}$ away to collect the meals from Kimiora, the main kitchen and dining house. Obviously, another crew was responsible for cooking all meals. This highlights the precision and faultless clockwork with which Türangawaewae Marae operates, as a principal marae of the Kingitanga, and the pride and care taken in extending hospitality to visitors. After breakfast, in accordance with tikanga 'custom', a kaumātua 'male elder' arrived to formally farewell Te Atiawa. These formalities concluded with votes of thanks followed by hongi 'the pressing of noses in greeting and fare-welling people', ${ }^{5}$ then hugs and kisses between the departing visitors and the hosts.

Our attention then turned to the clean-up. As we breakfasted, other cleaners, arriving to take care of their assigned areas of responsibilities, joined us. I was amazed by the diversity of jobs that needed to be completed. Most of these folk were local and middle-aged to elderly, and they spoke of how it would take them the rest of the week to complete the tasks on their rosters. Two uncles deliberated over which parts of the adornments from the waka taua they should start with, both agreeing they should dry the puhi-ariki 'upper feather streamers from the stern piece of the waka' before tackling the puhimoana-ariki 'feather streamers' from the taurapa 'sternposts' - steps to insure the waka parts would be safe until the next Regatta or their next outing.

\section{KO NGĀRUAWĀHIA TŌKU TÜRANGAWAEWAE: CONTEXTUALISING INFORMATION}

Drawing on several fulsome accounts of the Waikato Land Wars and the Kīngitanga Movement (e.g., Belich 1996, King 2003a, 2003b, McCan 2001, Rice 1992, Turongo House 2000, Ward 1973), this section provides some contextual information for my discussion of the Regatta event.

In the 19th century, the Waikato iwi and their allies endured three major battles within a nine-month period resulting in much loss of life: the first at Rangiriri in November 1863, the second at Rangiaowhia in February 1864 and, finally, at Ōrākau in March and April 1864. Earlier, both the original King Pōtatau (also known as Te Wherowhero) and his son, King Tawhiao ${ }^{4}$ who succeeded him, resided in Ngāruawāhia. "Their 'original pā' [traditional village]... was known as Pikiarero... [and] the location was at 'The Point', where the Waikato and Waipa rivers join" (Muru-Lanning 2010: 46). They considered this place their home and the capital of the Kingitanga. Here, Tawhiao felt secure. In 1863 that all changed with the Land Wars and the ensuing Crown confiscation of over 1,000,000 acres of fertile land. King Tawhiao and his Waikato people were driven out by this invasion and exiled to the forests of Te Rohe Pōtae, or the King Country (King 1984: 13) (Fig. 11), where they steadfastly refused to bear arms against the Government's soldiers. The words of his father King Pōtatau before his death had foretold what had 


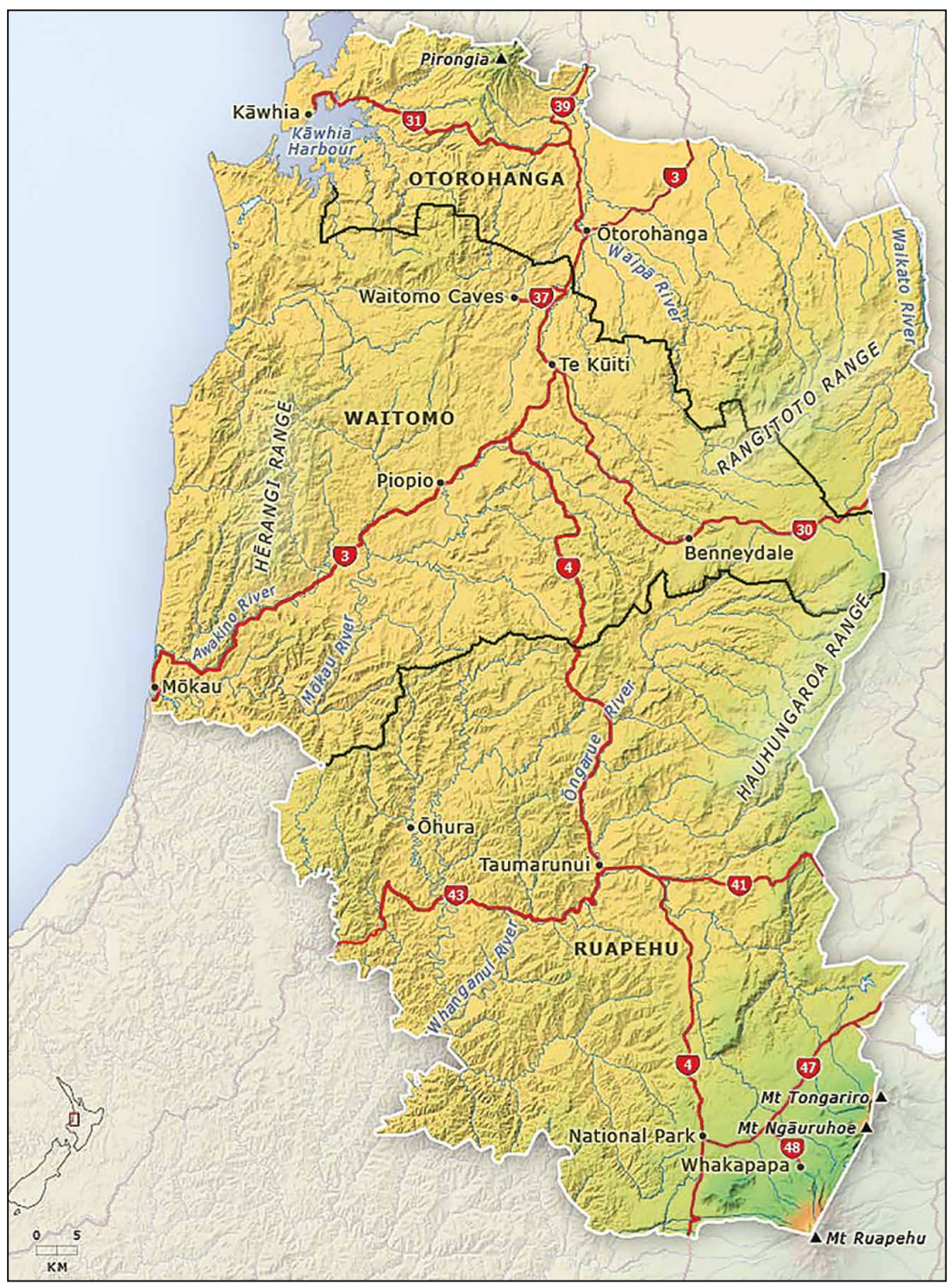

Figure 11. Map showing the King Country region where King Tawhiao sought refuge. (Image from http://www.teara.govt.nz/en/interactive/34819/ king-country-region-map.) 
come to pass for King Tawhiao: "Should war come upon this land, holdfast to the Nehenehenui..." (Turongo House 2000: 42). Te Nehenehenui was a name for the King Country, which became a place of refuge for Tawhiao and his followers.

King Tawhiao died in 1894, two years before the first official Regatta was held. Though he returned from voluntary exile in the King Country in 1881, he did not live again at Ngāruawāhia. When he and his followers visited the township, they found it had become a town with Pākehā owning the land and buildings; it was very different from the place he knew intimately as his former home. Lamenting his memories and weeping over his father's grave he uttered the second of two key tongi 'prophetic sayings' of that period, predicting his people's return in the future to the Ngāruawāhia he loved:

Ko Arekahānara tōku haona kaha,

Ko Kemureti tōku oko horoi,

Ko Ngāruawāhia tōku tūrangawaewae.

Alexandra will be a symbol of my strength of character,

Cambridge a washbowl of my sorrow,

And Ngāruawāhia my tūrangawaewae. (King 1984: 16, 2003b: 104)

Alexandra is a former name for Pirongia and is situated $40 \mathrm{kms}$ southwest of Ngāruawāhia. Cambridge is a further $38 \mathrm{~km}$ heading east from Pirongia, and $41 \mathrm{kms}$ south of Ngāruawāhia. As I understand it, this saying embodied and reflected the emotions Tawhiao was experiencing at the time. In particular, he referenced these three towns, describing the significance of these places to him. He had not long come out of exile and was visiting all the Pākehā towns that had been built on the confiscated or raupatu lands of his Waikato people (Turongo House 2000: 137). As he visited, he reiterated messages of peace to the Government with whom he had reconciled, and was well received by the new residents of each town. Despite their gestures of goodwill towards him, he still did not approve of or accept the Pākehā dominance apparent in those towns.

Several prophecies are attributed to Tawhiao. The first referred to here was uttered after the Rangiriri Battle in November 1863. As Tawhiao passed through Ngāruawāhia, filled with emotions of anger, pain and concern for his $i w i$, he climbed a knoll, Puke i ahua, and as he looked back, vowed: " $E$ kore tēnei whakaoranga e huri ki tua o aku mokopuna, ka puta ka ora-This suffering will not survive beyond the days of my grandchildren when we shall reach salvation" (Turongo House 2000: 60). Another translation is: "This phase of salvation shall not pass beyond the days of my grand-child, when we shall be reborn" (King 1984: 16). These words became embodied in the 
work and actions of Tawhiao's granddaughter, Princess Te Puea, who indeed created a türangawaewae (see below) for the grandchildren as prophecised by Tawhiao. She dedicated herself to the purchase of the old dumpsite on River Road and, after moving her people there from Mangatāwhiri in 1921, continued to raise money through the undertaking of various menial jobs to fund the building of Türangawaewae Marae at its current and original site. It was a long and arduous struggle with many, seemingly impossible and unimaginable hurdles to overcome, but one that was pursued nonetheless.

The messages were crystal clear and unambiguous from some of the Ngāruawāhia Pākehā town folk of the day. They did not want a Māori community establishing, or re-establishing in this case, on their doorstep. As "Ben" recounted:
As it was told to my father and passed down in our family, this house we live in here has been in our family since 1939. It used to be owned by a Mr Potter, a former money person of the time. When he got wind that [Princess] Te Puea was looking to buy land on this side of the river, near The Point here, close to where the original $p \bar{a}$ used to be, he convinced her that the current site [River Road] was the best value for money and the best place to be.

This history of struggle against the odds, resulting in triumph and emancipation, provides an unseen but never forgotten historical and political context to the significance of Türangawaewae Marae and part of the second prophetic quote by King Tawhiao mentioned earlier: "Ko Ngāruawāhia tōku tūrangawaewae; Ngāruawāhia shall be my footstool", alluded to in this section's title. King's biography of Princess Te Puea provides a fuller explanation (2003b: 104-5):

The expression 'turangawaewae' provides the key to understanding Te Puea's behaviour and her obsession for reciting Tawhiao's sayings. It has rarely been fully explained to non-Maori; it is perhaps difficult to explain. The concept has no precise equivalent in English. It is conventionally translated by the archaic biblical term 'footstool'. More recently it has been conveyed as 'a place to stand'. Literally it means 'a place where one puts one's feet'. But it has connotations of birthright, of ancestral continuity, of a place to which a person really belongs, of roots that are the source of identity and consequently the origin of the right to speak and behave as a Maori. For most older Maori, their turangawaewae is the place where they were born if that place has long-standing Maori significance; or it is the marae with which their family (traced through either parent) has been longest associated. Not having a turangawaewae is, in terms of recent tradition, tantamount to not having Maori credentials, not having the right to speak on the marae. 
Dean Mahuta (2010: 26) also referred to this Tawhiao saying, in writing about the establishment of Tūrangawaewae Marae:

Ki a au nei, ko ngā kōrero e pā ana ki te whakatūnga o Tūrangawaewae marae, ka tino whakamärama pai i te tikanga e kïia nei ko te 'türangawaewae', nā te mea, koia hoki têrā ko te tino pütake o te marae nei, hei türangawaewae mō Waikato, hei tūrangawaewae mō te Kingitanga, hei tūrangawaewae mō te ao katoa.

To me, the discussion relating to the construction of Türangawaewae Marae distinctly describes the word türangawaewae, because at its very heart that is what is meant, a place for Waikato to stand, a place for the Kingitanga to stand, a place for the world to stand. (author's translation)

Dislocation by war and the confiscation of the land did not deter, diminish or undermine the prophecy that Tawhiao's Waikato people would once again return to Ngāruawāhia, and this was accomplished by Te Puea's actions. King's (2003b: 105) commentary further described Tawhiao's reference to Ngāruawāhia as 'hei tūrangawaewae' as follows:

He [Tawhiao] was referring to Waikato's intimate association with that place, to the fact that his father had been confirmed in the kingship there, and to his own childhood and long residence there.... he was suggesting that the loss of Ngaruawahia symbolised and contained all the connotations of Waikato defeat.... His followers took the saying one step further... that until Ngaruawahia was re-established by Maori occupation, that the loss of mana would not be recovered.

The above quotes illustrate the deep-rooted connection of the Kingitanga movement to Tūrangawaewae Marae and Ngāruawāhia, and to Te Puea's desire to see her grandfather's prophecy come to fruition.

The memories of that war period, the invasion by the Imperial troops and the subsequent land confiscation have not been extinguished, nor has the significance of these actions and their subsequent impact on the Waikato people lessened. These issues were finally redressed by the Crown some 132 years after the event, when a Deed of Settlement was signed between representatives of the Crown and the Waikato-Tainui Tribe on 22nd May 1995. Five months before this event, on 21st December 1994, a Heads of Agreement document was agreed to, including three key points: a Crown apology for the Waikato land confiscations, a trust fund of $\$ 170$ million to acquire land, and the transfer of 14,483 hectares of Crown-controlled land back to the Waikato-Tainui Tribe (McCan 2001: 315). 


\section{TE AWA O WAIKATO —THE WAIKATO RIVER}

The Regatta is staged along the prominent and picturesque Waikato River (Fig. 12). The river has always held significance to Waikato $i w i$ and Waikato identity, both inextricably intertwined and bearing the same name. This is evident in many tribal sayings such as: He piko he taniwha, Waikato taniwha rau (At every bend in the river is a chief or guardian, Waikato of a hundred chiefs or guardians). It is also the subject of many tribal songs, for example: Waikato te awa (Waikato the river). The river runs from one end of the confederation of the Tainui waka tribes, ${ }^{7}$ traversing the regions of its four $i w i$, as well as other $i w i$, as it flows through the land. Described and venerated as an ancestor to some, as the life force of the tribe to others, and an obvious source of food and sustenance, it was once a renowned bustling highway of trade, commerce and communication between Auckland, Port Waikato and Hamilton, before the tribulations of 1863 . Having spiritual significance to yet other users of the river, Muru-Lanning (2010) wrote of the connection between those growing up at Türangawaewae Marae and the intimate associations they developed with the river, as illustrated in Hukiterangi Muru's reflections derived from his interview of January 2006:

The strength of the people is derived from the river. When we were growing up, every time we got sick our father would carry us on his back, throw a blanket over our shoulders and whoever was sick would be taken down there [to the river].... We would sit there and then my father would karakia [pray], ask for a blessing for us. (Muru-Lanning 2010: 47)

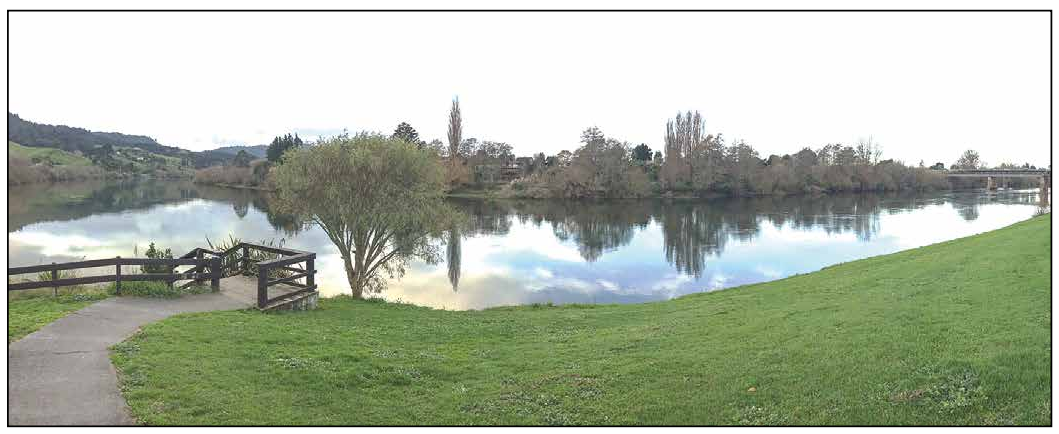

Figure 12. The Point showing the convergence of the Waipa River (left) flowing into the Waikato River (right) at Ngāruawāhia (August 2013). Beyond the bridge (at right) is Türangawaewae Marae and the venue for the Regatta since 1973. 
Over time the river itself had gradually become a casualty of ill-health owing to pollution, abuse and misuse by its various users. Many protracted and controversial arguments raged over the governance and guardianship rights to the Waikato River culminating in a Deed of Settlement signing between the Crown and Waikato-Tainui in 2009 (see Morgan and Te Aho 2013, Muru-Lanning 2010, Te Aho 2011, 2012). The settlement allowed the tribe more say in the scope of the river's co-management, state of health and care into the future.

With the continued interest and growth in water sports, particularly waka $a m a$, this was especially important. For example, one of the Waikato-Tainui tribe's investments is in Te Tira Hoe, a bi-annual hands-on opportunity for tribal members to learn about the awa. The journey begins at the source in Taupo, covers $300 \mathrm{kms}$ by road and moves downstream so the contingent can paddle some $125 \mathrm{~km}$ along the river in the process, before reaching the river mouth at Port Waikato. Involvement of the $i w i$ was also in keeping with the original intent of the Regatta "... to encourage various forms of aquatic sports and Māori activities..." (Ngāruawāhia/Tūrangawaewae Centennial Committee 1996: 5). It is hard to describe the Regatta without mentioning the Waikato River in the same breath, such is its importance and significance to the event, particularly after the venue relocation in 1973 from The Point to Tūrangawaewae Marae.

\section{EARLY REGATTA DAY FEATURES}

\section{Waka Taua and Official Salutes}

The Regatta is the sole New Zealand festival that allows the public an opportunity to view ornately carved waka taua (Fig. 13) except on the few occasions when Waikato waka have also appeared at Waitangi Day celebrations. The oldest of these waka, Te Winika, was originally built in 1845 by the Ngāti Tipa and Ngāti Māhanga hapū 'sub tribes'. With the threat of war pending in 1863, Major Von Tempsky and his Forest Rangers undertook to prevent Te Winika engaging in the war by breaking it into pieces. For 73 years, Te Winika lay in a muddy grave near Port Waikato, undisturbed until Princess Te Puea returned it to Türangawaewae (King 1984: 52). Te Winika was then restored to its previous state of splendour and has enjoyed many more years in the Regatta and other ceremonies of significance. This was the beginning of Princess Te Puea's efforts to revive canoe-building and racing in the 1930s. Te Winika was retired after the 1974 Regatta and gifted to the Waikato District Art Museum by the late Māori Queen, Dame Te Atairangikaahu. Two other waka taua, Rangatahi and Tumanako, both similar in age to Te Winika, also have a long association with the Regatta. Younger paddlers generally crew Rangatahi (the name means 'youth or the younger generation') and are drawn from Ngāti 

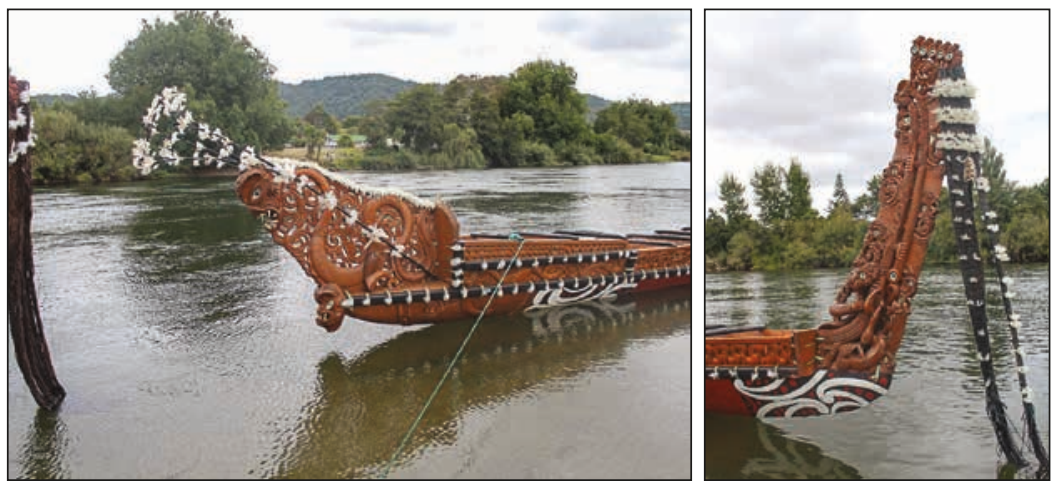

Figure 13. Ornately carved waka tana moored on the bank of the Waikato River. Photo from TRFB page, March 2013.

Koroki Kahukura. Hoturoa Barclay-Kerr (pers. comm, 2014) recollected that over the last 30 years different hapu on the river have been allocated to a waka. For instance, he explained that Tumanako paddlers are drawn from Türangawaewae and the Ngāruawāhia area. The waka Taheretikitiki, carved by the late Türangawaewae master carver Piri Poutapu, was launched in 1973. He added that Taheretikitiki, which is considerably younger than the other three, is predominantly crewed by paddlers from Māngere, Manukau, Papakura and Whātāpaka. This waka is the second to carry the Taheretikitiki name after the first one, built in approximately 1820 at Kaipara, was later gifted to King Tawhiao by Pāora Tūhaere of Ngāti Whātua (Ngāruawāhia/ Tūrangawaewae Centennial Committee 1996: 12).

The waka taua salutes easily command the most interest from the spectators on Regatta Day. This involves 20 to 30 warriors keeping perfect rhythm as they manoeuvre these remarkable vessels downstream where they make a turn. They then paddle upstream past the dignitary stage (today a barge) and salute the guests of the day, before returning to shore.

\section{Competitions}

During early Regatta a variety of fiercely-contested competitions were held throughout the day and most were for monetary prizes. In those early years, the aquatic component was made up of waka kopapa 'canoe hurdling' and kawhäki tamāhine 'chase for a bride', along with rowing and speed boat races. There were also mounted swimming races, requiring riders to be mounted on their horse at the start and finish of the race (Fig 14). 


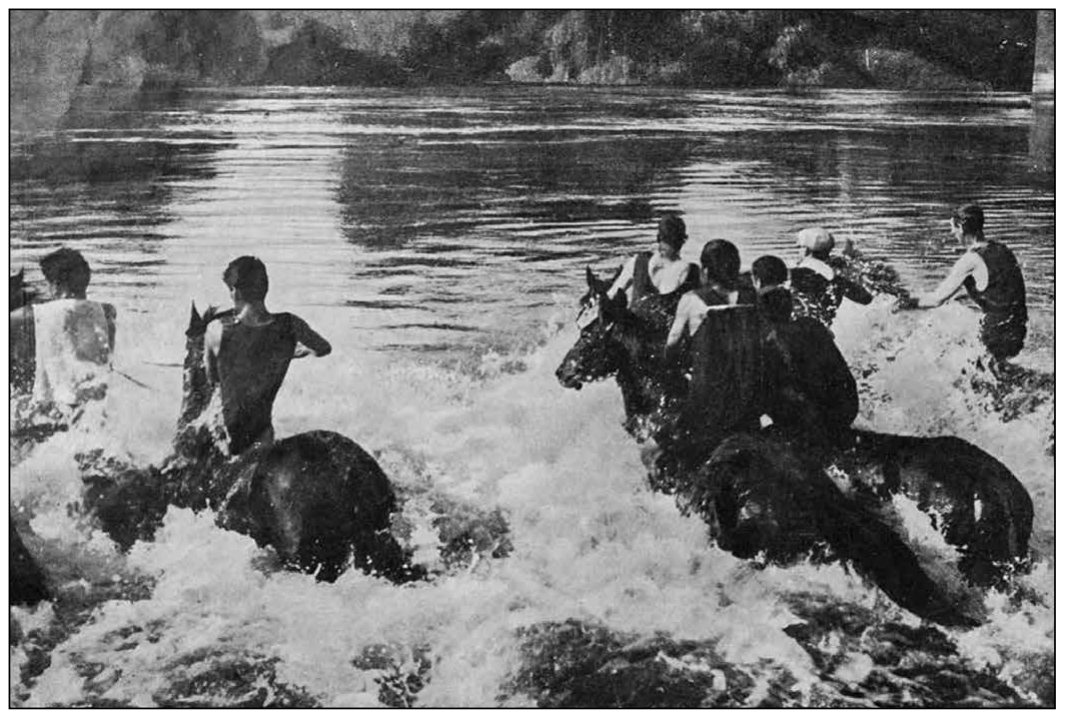

Figure 14. The start of the mounted swimming race at the Ngāruawāhia Regatta. (http://www.aucklandcity.govt.nz/dbtw-wpd/HeritageImages/Images/ AWNf/AWN_19100331_p006_i002_b.jpg)

The favourite competitive event was canoe hurdling (Figs 15 and 16). This race required two competitors in one canoe to negotiate a series of hurdles with cross-bars placed a foot or so above the water level. Upon approaching the hurdle, one person would continue paddling furiously, while the other moved along the canoe to ensure they could cross over the hurdle safely, without the canoe slipping backwards or the nose diving forward and the waka being swamped, or worse, sunk. The spectators delighted in watching the two-man crew either furiously paddling or frantically bailing out water. Canoe hurdling races were held for both men and women.

The other unusual event, 'chase for a bride', involved a Māori maiden or bride setting off in a waka only to be pursued by crews of six males in their own waka. The first crew to reach and hold the bride's waka were deemed to have captured her, and she would then board her captor's waka. The first to cross the finish line with the bride on board were announced the winners and awarded the prize. At any stage before crossing the line, the bride could be captured by any of the pursuing waka and could change waka any number of times before the end of the race. This race commemorates a true story 


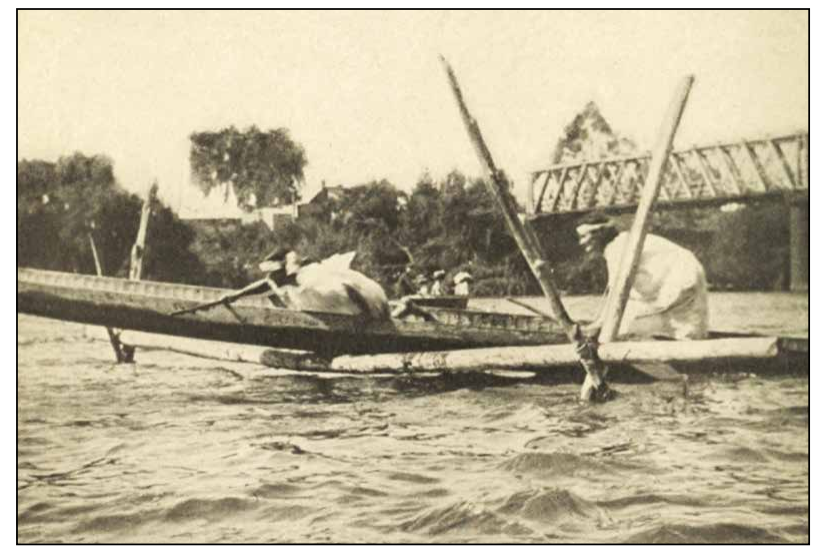

Figure 15. A Māori canoe hurdling race at Ngāruawāhia (http://www.gutenberg. org/files/41716/41716-h/images/illo_274b.jpg).

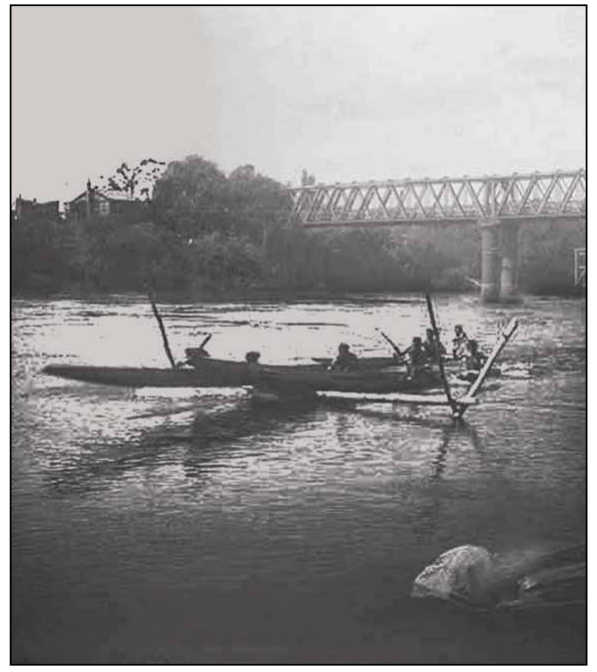

Figure 16. A waka taking part in hurdling races at the Ngāruawāhia Regatta on the Waikato River, and the railway bridge at right rear (Sir George Grey Special Collections, Auckland Libraries, 4-8595). 
but one with a more gruesome outcome for the well intentioned suitor of the original bride (Latta 1980: 281).

From early advertising posters it was evident that the events were clearly split and classified as either rowing events or Māori events, incorporating a mix of both aquatic and land based activities. The land based events often became part of the national calendar of events for those sports or competitions, such as Highland dancing, which was added to the Regatta repertoire in 1914. Marching girls and piping competitions were also on offer. A special barge, often provided by Mr Roose (Ngāruawāhia/Tūrangawaewae Centennial Committee 1996: 9), was anchored offshore from the main public area at The Point especially for the two Māori land based events: competitive Māori poi dance, in which a light ball on a string was swung or twirled in time to song or music, and the haka 'posture based dance' (Fig. 17). Iwi travelled to Ngāruawāhia primarily to participate in these popular, well contested events.

In 1961, two additional land based competitions, wood-chopping and sawing, were introduced and proved to be very popular. Another big drawcard in those early years was Wirth's "internationally famous circus and zoo from Australia" (Latta 1980: 277), the likes of which had never been seen before on that scale in New Zealand. The animals are no longer around but there remains the continuing appeal of the carnival rides and sideshows, which have remained a prominent part of Regatta over the years.

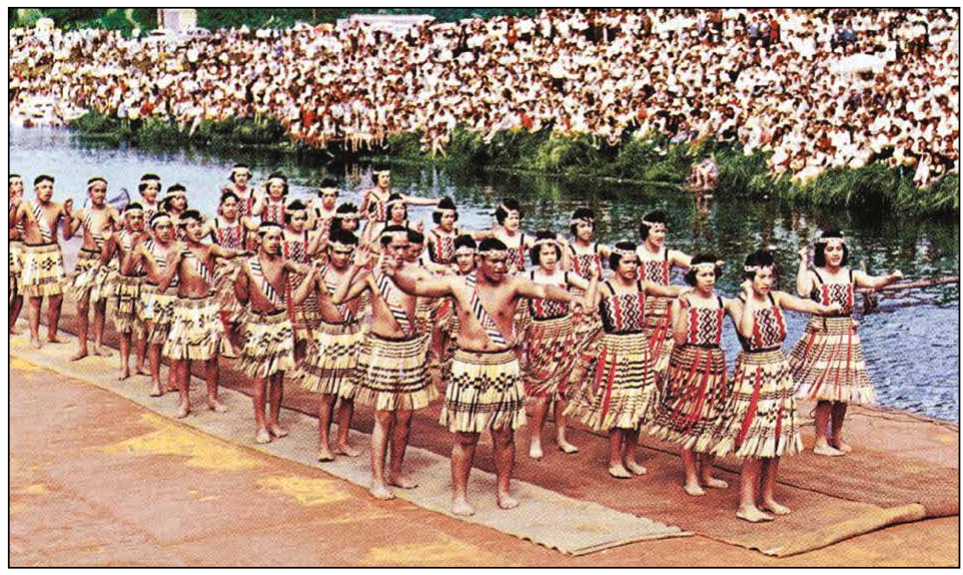

Figure 17. Performers on the barge at The Point during the Ngāruawāhia Regatta, 1965 (http://www.davidcade.net/images/PortraitPics/Ngaruawahia_ Royal_Regatta_1965.jpg). 


\section{Distinguished Guests}

Through the years prominent dignitaries have graced Regatta Days with their presence, and their numbers have extended beyond the paramount whānau 'immediate family' of the Kingitanga and local council members and politicians to other $i w i$ delegates from across the country, as well as international visitors. The practice stretches back to the origins of the first Regatta itself. According to "Ben", "In 1896 the Governor held the prime viewing spot of the day from the Squash Court balcony." In 1944, the Minister of Native Affairs and high ranking officers of the United States Army were the guests of honour (Evening Post, 27 March 1944: 6) as was the Governor-General, in 1963. In 1983 Prince Edward from Great Britain was a significant international guest. According to kuia 'female elder' Rena Ngataki (pers. comm, 2013), in former times many dignitaries requested an invitation to attend the day if one was not already forthcoming. On rare occasions members of aristocratic families from Tonga, Samoa, Hawai' $i$ or other islands, as well as other indigenous leaders, attended the Regatta, but usually they planned their visits for the week-long Coronation celebrations of the reigning Kingitanga monarch in August.

Some of the more interesting invitations to the Regatta were not to individuals but to groups such as bands. Locally, the Ngāruawāhia Pipe Band was formed after the Second World War and would often play at Princess Te Puea's request. American Marine bands, along with other military bands, are recorded as being in attendance over the years. During early Regatta, the bands played at the rotunda at The Point. The rotunda still stands in the same place today (Fig. 18). There is reason to believe that the distinguished guests are an intrinsic part of the Regatta; one is always nominated to receive the salute from the waka taua during the ceremonial passes. Also, on many occasions the current mayor of Ngāruawāhia is jointly extended this courtesy - another embodiment of kotahitanga at a local level.

\section{Regatta Locations and Hosts}

In the early years the Regatta was attended by thousands from nearby settlements and neighbouring towns, and even from further afield (Ngāruawāhia/Tūrangawaewae Centennial Committee 1996). Organised from the outset by the NRA, it attracted worldwide attention and was a notable event. In the early days, the Regatta was held at The Point where the Waipa joins the Waikato River, slightly to the northwest of the town (Fig. 19). Surplus funds raised from previous Regatta Days purchased the land at The Point, making this into a public reserve (Latta 1963: 47). As a place already renowned for its bustling river trade, The Point was a logical, even strategic, location to host such a prestigious event. It was also close to the old Ngāruawāhia 
railway station, an important factor when the main mode of travel to Regatta was by steam train. Extra trains were put on for the day to accommodate all who wished to attend. Many of the travellers did not enjoy the comforts of plush seats for the ride, but travelled in what were known as "cattle trucks":

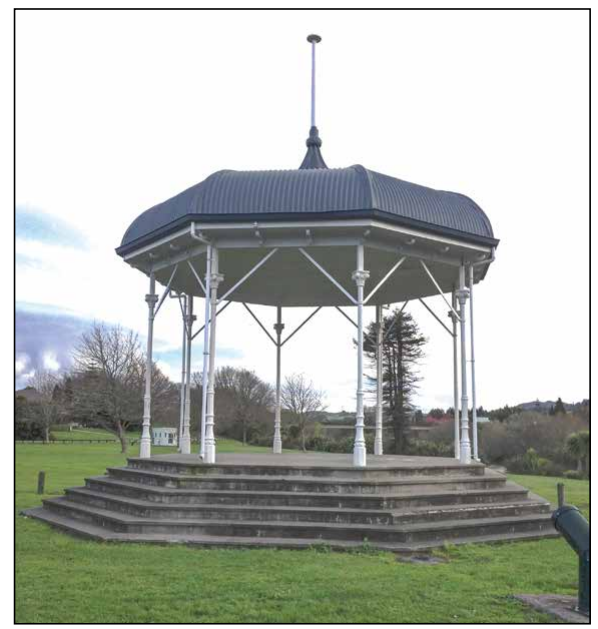

Figure 18. The band rotunda at The Point (August 2013).

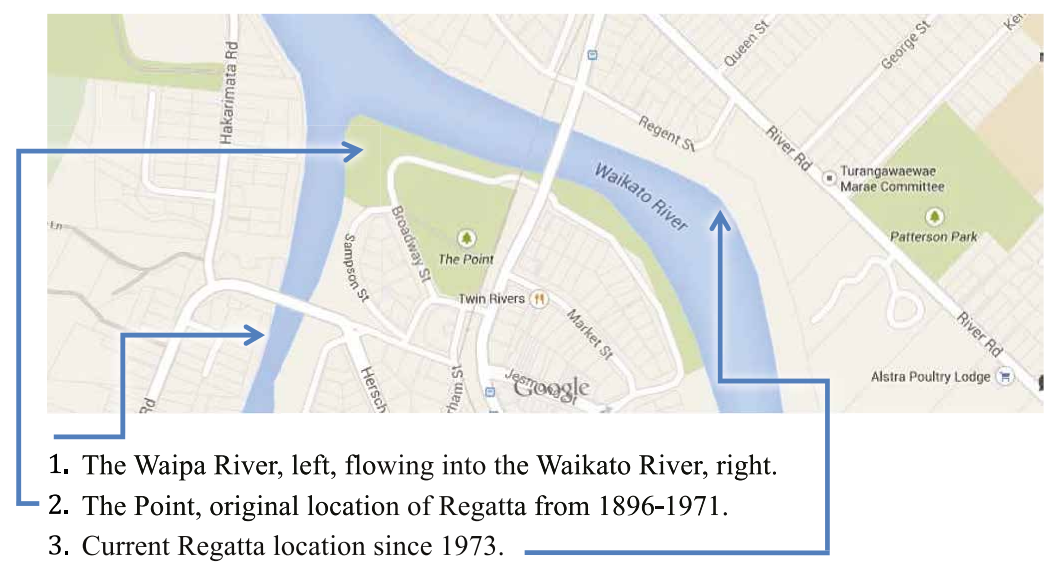

Figure 19. Map of past and current Regatta locations. 
These were long low freight waggons covered with railway tarpaulins, and seats back to back across and along the waggon. As the train moved at speed, 30 miles an hour if you please, the tarps flapped, smoke from the engine penetrated through to the passengers who were soon grimy and dirty but little the worse for their drafty ride. (Latta 1980: 277)

The Regatta was cancelled for the first time in its history in 1942, owing to the serious war conditions (Latta 1963:47), and as the community focussed on the important business of rallying support for New Zealand soldiers overseas (Latta 1980: 284; Ngāruawāhia/Tūrangawaewae Centennial Committee 1996: 4). On two further occasions, in the early 1940s, the Regatta was held at Türangawaewae Marae. On the second of these occasions, in 1945, it was hosted by King Koroki, the fifth Māori king, and Princess Te Puea to raise funds to build the Aotearoa meeting house. Some people remember that, for a time, two Regatta were held a week apart: One kuia 'female elder' commented "It was like a mini Regatta run by Te Puea over at the marae, then the big Regatta would be at The Point the following week". This was also referred to briefly account in Ngāruawāhia/Tūrangawaewae Centennial Committee (1996: 20) but scant detail is recorded. In 1972 the Regatta was cancelled because the river was in flood (Ngāruawāhia/Tūrangawaewae Centennial Committee 1996: 4) and caused the town to lose interest. In fact, the financial adversity suffered from cancelling the 1972 event meant that the NRA could no longer afford the financial risk of hosting it (Latta 1980: 283-84).

From 1973 the Regatta remained at Türangawaewae Marae permanently and the Kimiora Fundraising Appeal Committee from the Marae took over organisation of the day. This would also signal the formal involvement of the Kingitanga in the organisation of the Regatta up to the present.

The NRA, established in 1896, had successfully run the Regatta nearly continuously for 73 years. Revenue from the event also supported local initiatives such as the purchase of The Point. In 1944, it was the establishment of a Māori Health Clinic at Ngāruawāhia and, as noted earlier, building of Aotearoa meeting house in 1945. In 1973, Kimiora, the wharekai and cultural centre at Türangawaewae Marae, was the beneficiary of Regatta Day proceeds. During the early years at The Point, the workers running the Regatta on the day itself were waged, as the Regatta was run as a separate business entity under the NRA. When the responsibility for planning and organising the day shifted to the Marae, the changes in the socio-cultural importance of the event were reflected and embedded in all aspects of the day's operations, along with all roles and responsibilities which became voluntary. This continues right through to the current time with many dedicated people continuing to volunteer their time to ensure the annual Day's success. 


\section{KOTAHITANGA: CELEBRATING UNITY, ONENESS AND TOGETHERNESS}

Kotahitanga appears as a central notion underpinning the Regatta. The concept of kotahitanga has both social and political dimensions deserving of explanations far beyond the scope of this article. Benton et al. (2013: 145) have provided one definition of kotahitanga as "the state or circumstances of being one", which I translate here as unity, embracing oneness or togetherness. In a Māori worldview, it stresses the ties of relationships binding one person or group to another person or group, whether at whänau 'family', hapū 'sub tribe' or iwi 'tribe' level. Applications of kotahitanga can also transcend whakapapa 'genealogy' to include other social groupings at community, local, national and international levels.

Before 1863, the make-up of Ngāruawāhia was predominantly Māori and this was the capital of the Kingitanga. After the Rangiriri Battle of November 1863, the town was taken over by the troops and rebuilt as Queenstown, before being renamed Newcastle in 1870. In 1877 it returned to the name Ngāruawāhia (Swarbrick 2012: 5). Many of the early Pākehā settlers in Ngāruawāhia were descended from or had familial links to the military forces which occupied Ngāruawāhia and had established military redoubts at nearby towns of Hopuhopu and Pukekohe. Land allocations were also made to government soldiers after the Land Wars according to another Māori resident I will call "Koro". The new settlers and their descendants came face to face with their former enemies when King Tawhiao came out of exile in the late 1880s and eventually returned to Ngāruawāhia, and later when Princess Te Puea and others re-established themselves there in the early 1900s.

This brings to mind another of King Pōtatau's sayings to his son King Tawhiao, before his (Pōtatau's) death:

Kotahi anō te kohao o te ngira e kuhuna ai te miro mā, te miro pango, te miro whero.

There is but one eye of the needle, through which go the white, the black and the red threads. (Simpson 1992: 3)

There is another version of the same whakatauki 'proverb', with an added passage that is quoted less often:

Kotahi te kohao o te ngira e kuhuna ai te miro mā, te miro pango, te miro whero.

There is only one eye to the needle, through which the white, black and red threads must pass. 
I muri, kia mau ki te whakapono, kia mau ki te aroha, ki te ture. Hei aha te aha, hei aha te aha.

After I am gone, hold fast to faith; hold fast to love; hold fast to the law. Nothing else matters now-nothing. (Turongo House 2000: 42)

Every time I see the combination of white, black and red, this saying, which also appears in song and performance as well as the written verse, immediately comes to mind with its call for unity. Thinking about the Regatta, I interpret these words as embodying the mix of people of all nationalities and ethnicities in attendance, enjoying the multitude of festivities the event has to offer. The meaning given in the second version reads, "In other words all are equal in the sight of God" (Turongo House 2001: 197). Another interpretation from "Koro" expressed the same sentiment somewhat differently: "We are all born through a birth canal and enter the world in the same state".

Kotahitanga is reflected in the values of the Regatta, as attendees celebrate and enjoy the unity, the oneness and the togetherness that helps make the event what it is. At the same time the Regatta fosters social and cultural developments within the Ngāruawāhia community as a local, national and, in some respects, an international space with various dignitaries and visitors in attendance. People have not come to the Regatta under duress but have come of their own choosing or have been invited to attend for any number of reasons: to participate in and watch the waka kopapa races of their children or grandchildren, to eat together, to watch kapa haka group performances, to watch the spectacular waka taua parade, and/or to listen to the bands. The other important activity undertaken, by physically being at the Regatta, is to whakawhanaunga 'build or renew acquaintances or relationships'. The Regatta both exemplifies and underpins the notion of kotahitanga purely by bringing together a unique and diverse blend of people from the local community and beyond, to celebrate an event nearing its 120th birthday and to pay respects to the Kingitanga that has hosted it for over the past 40 years.

This is expressed in commentary from the centennial celebrations booklet where homage is paid to the ancestors and leadership of the day for "creating the links to bring Māori, Pākehā and a nation together". Credit also is given for "fostering a sense of social and cultural pride in the community" (Ngāruawāhia/Tūrangawaewae Centennial Committee 1996: 25).

My observations are not an analysis of the breadth and depths of the effect the Regatta has had over the years on the Ngāruawāhia community, but rather reflections on the Regatta as a way to test the state of relationships within the community.

To test assumptions I held, I sought out the views of some non-Māori Ngāruawāhia townfolk on the Regatta and the relationships between 
Māori and Pākehā within the town. Statistics New Zealand (2013) data for Ngāruawāhia has the Māori population at 60.5 percent and the Pākehā (European) population at 53.3 percent, with the total population numbering 5,127 (note: some individuals claimed multiple ethnicity categories). "Barney", a resident since 1952, commented that Ngāruawāhia is a good place to live and is considered by many to be a "Māori town" because of the Kingitanga. With limited mobility now compared to his earlier years, he no longer attends the Regatta but fondly recalled many positive memories. He remembered being allowed to take photographs on Türangawaewae Marae with blessing of "the Lady" - a term of endearment used by many in reference to the late Dame Te Atairangikaahu. When probed for thoughts about the modern Regatta, Barney's response was; "I think it's a bit too dear [expensive] now to go from what I hear and a bit more money driven. It wasn't like that before. Most non-Māori you see at the Regatta now are not from here you know, not from Ngāruawāhia." He was very adamant, however, that Māori and Pākehā relationships in the town are very good.

"Jake" had the privilege of growing up on the outskirts of Ngāruwāhia for 20 years around 1973, when his grandfather purchased a large farm bordering the Waikato River and close to the Regatta venue. Schooled in Hamilton and then Auckland, his family travelled past Türangawaewae Marae twice a day:

I could see all the buses and cars and vehicles outside so I knew something big was happening there, at the hui [a meeting], but wasn't quite sure what it was all about and whenever I asked I was told it didn't concern us. Our lives revolved around the farm, our schooling, rowing and the riding school. We bypassed the whole [Regatta] thing.

Pressed about his recollection of Māori and Pākehā relations in the community, he responded that other than rugby (which was a huge thing for his family), the Anglican Church, pony club and riding for the disabled, they did not really mix with the local community. They shopped in the larger city of Hamilton so they had little need to go into the Ngāruawāhia township itself and rarely did. It was not until his brother decided to take a job at the freezing works, that he and his brother made real connections with the community. They got to know their Māori co-workers with whom his brother worked for three summers. He said his brother always describes those times as the best experience of his life. Reflecting upon the late Dame Te Atairangikaahu's death, and having watched the funeral procession on television at his work place, he recounted how many of his colleagues were in awe about it all. They naturally assumed he was very familiar with Māori customs and Tūrangawaewae Marae, and were envious of him, especially as he grew up there. In that instance he lamented a lost opportunity to learn 
about another people and culture that was right on his back doorstep. It did foster within him, however, an appreciation for tikanga Māori that has had more significance to him in his adult years and current career, and given him a way to satisfy those curiosities long held from his boyhood.

"Ben" has lived his whole life in Ngāruawāhia and his family for nearly 100 years before him. His wife "Peg" also was born in the town and their children still live in the town, as do their grandchildren, all whom are part Māori. In his words: "Ngāruawāhia is a bloody good town and I don't like it when out-of-towners come in here and start running the town down. I mean what would they know about it?" He had been a past representative on the local council. As a result, he knew many of the community leaders on "both sides of the bridge" in person, enabling him to span what is sometimes jokingly referred to as a physical point of segregation in the town. The bridge separates those on the northern side, associated with the marae, or the Mãori community, from those on the southern or "town" side, which is where most Pākehā live. While "Ben" and "Peg" no longer attend Regatta, they often watch the happenings from the bridge or "this" southern side of the riverbank as their grandchildren are usually participants in the waka kopapa races. The others who regularly gather on the southern banks are also locals who have long had the practice of setting up their picnic spots and spectator chairs to enjoy the waka kopapa and waka taua parades. The spot receives annual lawn mowing by the Council and gives these spectators the freedom to set themselves up and picnic without the fuss and expense of going to the actual Regatta venue itself directly across the river. "Peg" reflected: "Once the Regatta moved permanently to the Marae the numbers went down, interest fell away by the local non-Māori and some local Māori too. That's really when a lot of the non-Māori events stopped too. I guess the economics of the day didn't help either." These comments suggest a waning interest by parts of the Ngāruawāhia community in attending and participating in the Regatta. What, though, was the real underlying cause? Inevitably the change in organisers, along with the shift of location to the Marae, could be attributed to the disappearance of some activities. Events that had been regular features of Regatta for years were gradually withdrawn from the programme. From 1973, the Regatta truly became an annual fixture of Kingitanga celebrations as Türangawaewae Marae became the new host location and organiser of the event, right through to today.

Regattas held at The Point still hold many special memories for "Ben" and "Peg", especially the "free Friday nights for locals" which they attended as teenagers. They remembered the smallest of details of stalls, entertainment and activities, right through to the order of the events on the day. As they rattled off the list of stands that were erected at The Point, I was amazed that 
everything fit into the space, along with the thousands of people in attendance in those days. The expressions on their faces were a joy to watch as they relived these former times and as I sat and listened, I too was transported to another time. "Ben", a coxman and oarsman in his time, recounted wistfully how he wished the Regatta was back at The Point again (see Fig. 12), in all its former glory. When asked why the interest had dropped among the locals in attending present-day Regatta he replied, "It's just too pricey now, by the time you pay the entry fee, the rides and then food, it all adds up".

Despite their own reasons for no longer attending Regatta, "Ben" and "Peg" still considered Regatta a great opportunity for Ngāruawāhia youth to share and explore interests in aquatic sports with local, national and even international visitors. This has come to pass with many Türangawaewae rangatahi 'youth' representing New Zealand in national waka ama crews. "It's a focal point for the community, it's brilliant to see that the Regatta is still going on today in some form or shape", was "Ben's" conclusion. Irrespective of which riverbank you view the Regatta from, the kotahitanga kaupapa or theme of the Regatta continues to unite people at community, local, national and international levels.

\section{COMPARISONS OF HISTORICAL REGATTA AND THE 2013 EVENT}

Seated among the mixed generations at the breakfast table on that Sunday in 2013, I asked my relatives about their Regatta experiences over the years. They mused about many things, how the crowds nowadays, for example, were fewer in number than in previous years. They said attendance varied and were influenced by a number of factors including the weather, the year of celebration, and even knowing which esteemed visitors would be in attendance. "What was the drawcard?" I asked. "Why do people keep coming back?" My relatives gave a variety of answers in response:

- Seeing the skill levels required of the paddlers to turn the waka taua in time to make the salute to the visitors and the crowd gathered at the barge and stretched right along the riverbank. That's always a buzz cos you never know if they'll make the turn in time!

- The food, particularly the hāngi and the 11 am waka parade. We go at 11 am so you are guaranteed a hāngi, otherwise you will probably miss out.

- Keeping up our traditions - but if it rains we don't go.

- The kapa haka and bands, so you don't have to rush.

- The schools' waka races [on the Friday], geez our kids are mean [tough] ... and fearless!

- Well cuz [cousin], all I can say is that when we are asked to support the kaupapa [the reason for an event - Regatta in this case], we don't question that; we just come and do the mahi [work]. 
I can identify with all six and would add there are many other reasons from a sentimental as well as a traditional point of view. I also heard of others from Türangawaewae who choose this as the one event of the year for which they return home from Australia to rekindle their whakapapa links. As I wandered among the throngs of people, I asked the same question of acquaintances and some complete strangers. The most common reasons given were: watching the waka taua ceremonial parades and eating hāngi or other delicacies. While the Regatta can be termed a uniquely Waikato experience, it still holds widespread appeal.

Since the inception of the Regatta, it has essentially been a self-funding, not-for- profit event that has also served as a fundraising mechanism for local projects. The executive committee of the NRA did this successfully for 73 years. This was continued throughout the 1940 s by Princess Te Puea, up until her death in 1952. When the location of the Regatta moved to Türangawaewae Marae permanently in 1973, this fundraising feature was also retained. Wynae Tukere (pers. com. 2013) told me that should a surplus arise, after taking care of the incurred expenses of running the day, this amount is reinvested into the Türangawaewae Marae Committee.

Another significant difference from earlier Regatta run by the NRA would be the financial support provided by the Türangawaewae Marae Committee to ensure the day is held. Despite other views shared earlier in this article, entry charges are still kept to a minimum to encourage whannau and visitor attendance, as is the newly introduced marae tour fee. The discussion does not dwell on whether the Regatta should be held each year, but is detailed about what the programme will feature and whether any past events might be feasible returns to the programme in the future. The idea has also been raised about how the Committee should set about garnering a youth perspective on what the Regatta programme should feature from a cultural, heritage and language perspective in the future.

At earlier Regatta, aquatic activities such as canoe hurdling and chase for a bride races, and the rowing, speedboat and mounted swimming races dominated the day, along with the waka taua ceremonial parades. The land based activities were competitive poi, haka and Highland dancing performances, piping, wood-chopping and sawing competitions, and the carnival sideshows. Today, waka kopapa, kapa haka, bands, food, and merchandise stalls, information stands and the waka taua ceremonial parades, along with the carnival rides and sideshows are the most popular features.

Advertisements about the Regatta appeared regularly in newspapers during the early years, especially in the lead-up to the day itself. This year's advertisements were also on Radio Tainui airwaves, as well as the Tūrangawaewae Regatta Facebook social networking page. A roving reporter 
was taking photographs and uploading them instantaneously to Facebook. Radio Tainui was also broadcasting live from the Regatta where you could hear the emcee informing the crowd of the upcoming events as the day unfolded. Rangatahi 'the younger generation' all around me were busy on their cellular telephones with applications such as Instagram and Snapchat, sending "selfies" or images of themselves and friends at the Regatta.

From my observations, only the waka kopapa finals and the OC1 waka race awarded monetary prizes this year. The waka taua ceremonial parades did not involve competition or prizes. The kapa haka performances were all ngahau 'entertainment', as were the bands, so no prizes were awarded.

$$
* * *
$$

On the 17th March 1896, a common ground was founded at The Point in hosting the inaugural Regatta. It has been built into an event that has endured for 118 years. The Regatta is but one expression of kotahitanga, which celebrates and reminds us of the history and the progress made between two groups of people of seemingly differing worldviews within a single community. This is despite the viewing and celebration of this event and its related activities from both sides of the river by different parts of that community.

The Waipa and Waikato Rivers' convergence at The Point is also symbolic of the coming together of these two parts of that community. One side represented the staunch supporters of the Kingitanga, the other predominantly have familial links to military forces who had not so long ago been on the opposing side of a short but ferocious land war, invasion and subsequent land confiscation. The former group were identified by their Māori whakapapa and had long settled and lived at Ngāruawāhia under Kings Pōtatau and Tawhiao before the Land Wars; the latter were of colonial stock and occupied or moved to Ngāruawāhia after the Land Wars, most likely as part of the land allocation scheme for military soldiers. While those who whakapapa to the rohe 'tribal territory' are still present in the community in good numbers, others within the township may not have the same familial links to the military forces of old, but have still been residents within the town for generations.

Today the Regatta is inextricably associated with Tūrangawaewae Marae and the Kingitanga. This has been more pronounced since the mid-1940s, and with the permanent venue relocation in 1973, and continues to echo the sentiments of King Tawhiao's well-known tongi: Ko Ngāruawāhia tōku Türangawaewae, 'Ngāruawāhia shall be my footstool.'

Two of Tawhiao's many tongi have guided us through this description of the Māori concept of unity and the deep connect to Tūrangawaewae. It is therefore fitting to conclude with another that epitomises kotahitanga as 
explained by Paraone Gloyne, a Ngāti Raukawa Māori Language Revitalist, in a recent Māori Television broadcast:

Ki te kotahi te kākaho, ka whati; ki te kāpuia, e kore e whati.

If the kākaho [a type of swamp reed] grows on its own, it will break; if it grows in a bunch or the stems are large, they will not break. (Mohi 2013)

In reference to people, I take this tongi to mean that those who stand alone will not prosper or reap the benefits as much as those who work together or in unison. Similarly, many hands toil in the weeks leading up to the Regatta so the day itself can be enjoyed by the multitude of visitors to Türangawaewae Marae and Ngāruawāhia, and for generations to come.

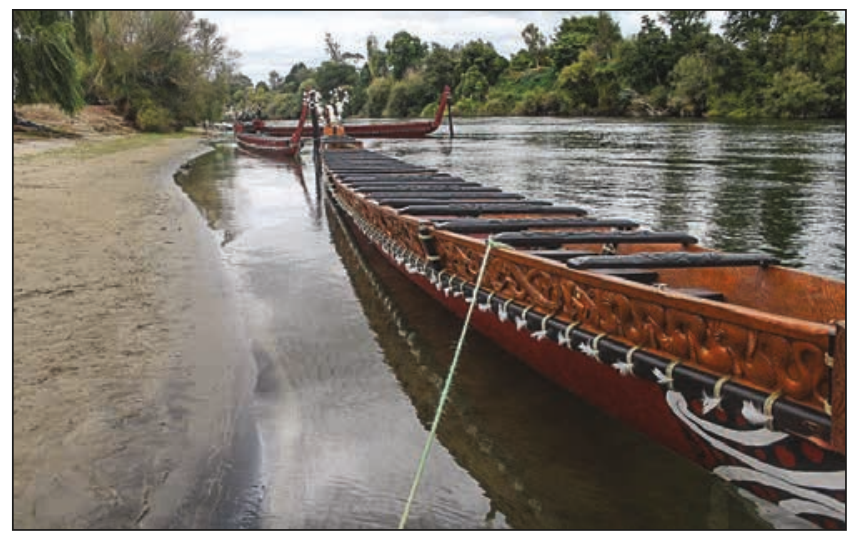

Figure 20. Tätahiora at rest on the Waikato River. Commissioned in 2007, it will help carry the Regatta into the 21st century. Photo from TRFB page, March 2013.

\section{HE MIHI MAIOHA}

He mihi tēnei ki ōku hoa mahi o mua $i$ au e whakaako tamariki ana $i$ Waikato, $i$ tūwhera mai ō kōrua ngākau ki te whakahua mai i ngā kōrero mō ngà kaihoe nō ō kōrua kura. Nei ka mihi. He mihi hoki ki ōku whanaunga, ki tōku kuia, ki tōku koro me ngā hoa pümau i kōrero mai i ō koutou whakaaro rangatira e hāngai ana ki te rīkata, i ō koutou mōhiotanga rānei ki ètahi kaupapa o te rīkata, te whakahaere rīkata me ōna whakanikoniko katoa. Ka mutu ka mihi atu ki ngā kainoho Pākehā ake o Ngāruawāhia, nā koutou hoki ètahi kupu i koha mai ki tēnei tuhinga kia tōtika ai te tirohanga atu ki tênei kaupapa i roto i te hāpori. Tēnā hoki koutou. 


\section{ACKNOWLEDGEMENTS}

A heartfelt thank you to my two former teaching colleagues who openly and graciously shared commentary with me about their student paddlers participating in the waka kopapa races on the Friday. I must also acknowledge my relatives, my elders and close friends and acquaintances who offered valuable insights, explanations and details about the many facets of Regatta planning and implementation, and particularly why the Regatta remains of significance to each and every one of them. Finally, to the non-Māori community members who kindly offered their thoughts about their experiences with the Regatta as long-time residents of Ngāruawāhia, my sincere thanks and gratitude to you all. All photographs are by the author, except where otherwise indicated.

\section{NOTES}

1. Here and elsewhere in the text, fictitious names have been given to townspeople and friends, former teaching colleagues and acquaintances who have kindly contributed anecdotal information to this article. These names are denoted by quotation marks.

2. An annual, week-long celebration in August held to commemorate the current monarch's day of crowning and remember the passing of the previous monarchs.

3. Incidentally my daughter would later return to play softball for the Türangawaewae club, among her relations as a seven year old, making the weekly commute for a season as we, her parents, had done previously for netball and rugby.

4. The spelling of kopapa and King Tawhiao, without macrons over the initial vowels, is deliberate and follows from consultation with tribal elders. These renderings also are consistent with spellings used on the Waikato-Tainui webpage (see http://www.waikatotainui.com/).

5. Also an expression describing the meeting/union of each participant's ancestors.

6. Another translation of these words is slightly different:

Alexandra will ever be a symbol of my strength of character;

Cambridge a symbol of my washbowl of sorrow;

And Ngāruawāhia my footstool. (Turongo House 2000: 138)

7. The confederation of tribes of the Tainui waka consists of Waikato, Ngāti Raukawa, Hauraki and Maniapoto. The Waikato River also traverses the Ngāti Tūwharetoa and Te Arawa regions.

\section{REFERENCES}

Belich, J., 1996. Making Peoples. A History of New Zealanders: From Polynesian Settlement to the End of the Nineteenth Century. Auckland: Penguin.

Benton, R., A. Frame and P. Meredith (eds), 2013. Te Mātāpunenga: A Compendium of References to the Concepts and Institutions of Māori Customary Law. Wellington: Victoria University Press.

Evening Post. Issue 73, 27 March 1944. Available at: http://paperspast.natlib.govt.nz/ 
King, Michael, 1984. Te Puea Herangi: From Darkness to Light. Wellington: School Publications Branch, Department of Education.

2003a. The Penguin History of New Zealand. Auckland: Penguin.

2003b. Te Puea:A Life. Auckland: Reed.

Latta, Albert M., 1963. Meeting of the Waters-The Story of Ngāruawāhia. Ngāruawāhia: Ngāruawāhia Borough Council.

1980. Meeting of the Waters_-The Story of Ngāruawāhia. Ngāruawāhia: Ngāruawāhia Lions Club.

Mahuta, Dean Patariki Smeatham, 2010. Ko te awa tōku piringa ka puta, ka ora-he tangata, he whenua, he tangata whenua. Unpublished PhD thesis, Auckland University of Technology.

McCan, David, 2001. Whatiwhatihoe:The Waikato Raupatu Claim. Wellington: Huia Publishers.

Mohi, Hinewehi (Kaihautū/Producer), 2013. Whakatauki [Television Broadcast], 4 November. Auckland: Māori Television.

Morgan, T.K. and L. Te Aho, 2013. Waikato Taniwharau: Prioritising competing needs in the management of the Waikato River. In J.A. Daniels (ed.), Advances in Environmental Research 29. Nova Science Publishers, pp. 85-105.

Muru-Lanning, Marama, 2010. Tupuna Awa and Te Awa Tupuna. An Anthropological Study of Competing Discourses and Claims of Ownership to the Waikato River. Unpublished PhD thesis, The University of Auckland.

Ngaruawahia/Turangawaewae Centennial Regatta Committee, 1996. A Centennial History: The 100th Year Regatta. Te Rautau Whakanui. The Ngaruawahial Turangawaewae Maori Aquatic Regatta 1896-1996. Ngaruawahia: Ngaruawahia/ Turangawaewae Centennial Regatta Committee.

Rice, Geoffrey W. (ed.), 1992. The Oxford History of New Zealand. 2nd edition. Auckland: Oxford University Press.

Simpson, Miria (ed.), 1992. He Rourou Iti: Selected Speeches of Te Arikinui Dame Te Atairangikaahu. Wellington: Miria Simpson and Daphne Brasell Associates Press.

Swarbrick, Nancy, 2012. Waikato places - Ngāruawāhia, Te Ara - the Encyclopedia of New Zealand, updated 11-Dec-12. Available at: http://www.TeAra.govt.nz/ en/waikato-places/page-5

Statistics New Zealand, 2013. Quick Stats about Ngāruawāhia. Available at: http://www.stats.govt.nz/Census/2013-census/profile-and-summary-reports/ quickstats-about-a-place.aspx $?$ request_value $=13685 \&$ tabname $=$ Culturaldivers ity\&sc_device $=$ pdf

Te Aho, Linda, 2011. Waikato: River of life. In J. Ruru, J. Stephenson and M. Abbott (eds), Making Our Place: Exploring Land-use Tensions in Aotearoa New Zealand. Dunedin: Otago University Press, pp.145-157.

2012. Ngā whakatunga waimāori: Freshwater settlements. In N.R. Wheen and J. Hayward (eds), Treaty of Waitangi Settlements. Wellington N.Z.: Bridget Williams, pp.102-113.

TRFB (Tūrangawaewae Regatta Facebook). Available at: https://www.facebook.com/ pages/Turangawaewae-Regatta/336141919834012 
Turongo House, 2000. Tāwhiao - King or Prophet. Ngāruawāhia: MAI Systems. 2001. Te Arikinui and the Millennum of Waikato. Ngāruawāhia, N.Z.: Rice Printers.

Ward, A., 1973. A Show of Justice: Racial "Amalgamation" in Nineteenth Century New Zealand. Auckland: Auckland University Press.

\begin{abstract}
The 118th Ngāruawāhia Tūrangawaewae Regatta was celebrated on the 16th of March 2013. First held on the 17th March 1896, it is the second oldest regatta in New Zealand behind the Auckland Regatta of the 1870s. Renowned for the majestic fleet of ornately carved waka taua 'war canoes' on parade, crowds still flock to Ngāruawāhia today to watch the waka taua make their annual salute to King Tuheitia, the 7th monarch of the Māori King Movement, and his dignitaries. This narrative details my journal observations of March 2013 from the Waikato River banks, before delving into historical information detailing the advent of the Regatta, the Māori King Movement's historical capital base and relocation, and the significance of these to Regatta. The next section speaks of the Waikato River connection, along with early Regatta features, and the promotion of kotahitanga 'embracing togetherness' within the Ngāruawāhia community, the Waikato Region and more generally across Aotearoa/NewZealand. The article concludes with a comparison of early Regatta and that of 2013.
\end{abstract}

Keywords: Ngāruawāhia Tūrangawaewae Regatta, Māori King Movement, Kingitanga, kotahitanga, waka taua, Waikato River, New Zealand History

\title{
CITATION AND AUTHOR CONTACT DETAILS
}

Rewi, ${ }^{1}$ Tangiwai, 2015. The Ngāruawāhia Tūrangawaewae Regatta: Today's Reflections On The Past. Journal of the Polynesian Society 124 (1): 47-81. DOI: http://dx.doi.org/10.15286/jps.124.1.47-81

${ }^{1}$ Corresponding author: Te Tumu, School of Māori, Pacific \& Indigenous Studies, University of Otago, New Zealand. E-mail: tangiwai.rewi@otago.ac.nz 
